\title{
PENGARUH PEMBINAAN KEPALA SEKOLAH DAN KINERJA MENGAJAR GURU TERHADAP KUALITAS PROSES PEMBELAJARAN SISWA KELAS V PADA SD NEGERI DI KECAMATAN CIAWIGEBANG KABUPATEN KUNINGAN
}

\author{
Komar SP
}

SD Ciawilor 1, Ciawigebang, Kuningan - Jawa Barat, komarunwir@gmail.com

\begin{abstract}
ABSTRAK
Perhatian utama dilaksanakannya penelitian ini adalah untuk mengetahui besaran pengaruh pembinaan oleh kepala sekolah dan kinerja mengajar guru baik secara parsial maupun ganda terhadap kualitas pembelajaran siswa kelas V pada sekolah dasar negeri di Kecamatan Ciawigebang Kabupaten Kuningan. Metode yang digunakan adalah melalui pendekatan kuantitaif. Hasil penelitian menunjukkan bahwa: (1) Terdapat pengaruh yang positif dan signifikan pembinaan oleh kepala sekolah terhadap kualitas proses pembelajaran (2) Terdapat pengaruh yang positif dan signifikan kinerja mengajar guru terhadap kualitas proses pembelajaran (3) Terdapat pengaruh yang positif dan signifikan pembinaan oleh kepala sekolah dan kinerja mengajar guru secara simultan terhadap kualitas proses pembelajaran Berdasarkan kesimpulan yang telah disampaikan di atas, penulis menyarankan, bahwa: (1) Kepala sekolah sebagai manajer pada satuan pendidikan perlu terus meningkatkan kemampuan manajerialnya serta berusaha memberikan keteladanan bagi guru baik dari sifat maupun sikap agar dalam proses pembinaan guru lebih mudah diikuti (diteladani) oleh guru sehingga dapat mendorong peningkatan kualitas proses pembelajaran. (2) Kualitas proses pembelajaran kelas V sudah termasuk baik. Tetapi hendaknya terus ditingkatkan dan diekstensifkan juga dengan tingkatan kelas lainnya.
\end{abstract}

Kata kunci: Pembinaan, Kinerja Mengajar, Kualitas Proses Pembelajaran

\begin{abstract}
The main concern of this research is to find out the magnitude of the effect of coaching by the school principal and teacher performance both partially and doubly on the quality of learning of fifth grade students in public elementary schools in Ciawigebang Subdistrict, Kuningan District. The method used is through a quantitative approach. The results showed that: (1) There was a positive and significant influence of coaching by the principal on the quality of the learning process (2) There was a positive and significant effect on the teaching performance of teachers on the quality of the learning process (3) There was a positive and significant influence on the guidance of the principal school and teacher teaching performance simultaneously on the quality of the learning process Based on the conclusions presented above, the authors suggest, that: (1) Principals as managers in educational units need to continue to improve their managerial abilities and try to provide an example for teachers both from the nature and attitude so that in the process of guiding teachers more easily followed (imitated) by teachers so as to encourage the improvement of the quality of the learning process. (2) The quality of class $\mathrm{V}$ learning process is already good. But it should continue to be improved and intensified also with other grade levels.
\end{abstract}

Key words: Coaching, Teaching Performance, Quality of Learning Process 


\section{PENDAHULUAN}

Ketika penulis mengadakan observasi dalam rangka pra survey, terlihat fenomena yang berkaitan dengan kualitas proses pembelajaran siswa kelas $\mathrm{V}$ pada sekolah dasar (SD) Negeri di Kecamatan Ciawigebang Kabupaten Kuningan dan dianggap memerlukan penelitian lebih lanjut, yaitu: (1) Masih lemahnya kemauan untuk memperbaharui dan mengembangkan perencanaan pembelajaran. Para pendidik cenderung menggunakan rencana pelaksanaan pembelajaran (RPP) yang sudah dibuat pada tahun sebelumnya. Seolah-olah RPP itu instrumen baku yang tabu untuk diadakan perubahan. (2) Pada proses pelaksanaan pembelajaran, masih terlihat kurang mengindahkan tahapan-tahapan yang sudah baku namun fleksibel dalam substansinya yang mengakibatkan alokasi waktu menjadi kurang proporsional. (3) Proses penilaian atau evaluasi masih harus mendapatkan perhatian yang serius. Terdapat kecenderungan instrumen untuk mengukur tingkat keberhasilan siswa dalam memahami materi ajar kurang komprehensif.

Mengacu kepada keseluruhan paparan di atas, maka dalam upaya memahami dan memecahkan masalah pengelolaan pembelajaran, dirasakan perlu dan penting dilakukan penelitian tentang pengaruh pembinaan kepala sekolah dan kinerja mengajar guru terhadap kualitas proses pembelajaran.

Manajemen pendidikan adalah melakukan pengelolaan sumber daya yang dimiliki oleh sekolah atau organisasi yang diantaranya adalah manusia, uang, metode, material, mesin dan pemasaran yang dilakukan dengan sistematis dalam suatu proses. (Rohiat, 2010).

Mutu didefinisikan sebagai M-Kecil dan M-Besar. M-Kecil adalah mutu dalam arti sempit, berkenaan dengan kinerja bagian organisasi, dan tidak dikaitkan dengan kebutuhan semua jenis pelanggan. M-Besar adalah mutu dalam arti luas, berkenaan dengan seluruh kegiatan organisasi yang dikaitkan dengan kebutuhan semua jenis pelanggan. M-Besar inilah yang dimaksudkan dengan mutu terpadu. (Juran, 2000)

dalam pengertian mutu terkandung makna "kesesuaian dengan kebutuhan". (Crosby, 2001)

"Quality a basic business strategy that provides and service that completely satisfy both internal and external customers by meeting their explicit expectation." (Tenner dan De Toro, 2002). Hal ini dapat dianalisis bahwa 
kualitas merupakan strategi dasar dalam menyediakan layanan untuk memuaskan pelanggan.

Mutu adalah "paduan sifat-sifat produk yang menunjukkan kemampuannya dalam memenuhi kebutuhan pelanggan, baik kebutuhan yang dinyatakan atau kebutuhan yang tersirat, masa kini dan masa depan". (Tampubolon, 2001)

Undang-undang Sistem Pendidikan Nasional Nomor 20 tahun 2003 menyatakan bahwa: "Pembelajaran adalah proses interaksi peserta didik dengan pendidik dan sumber belajar pada suatu lingkungan belajar".

"Pembelajaran pada hakekatnya adalah proses interaksi antara peserta didik dengan lingkungannya, sehingga terjadi perubahan perilaku ke arah yang lebih baik”. (Mulyasa, 2002)

Cronbach menyatakan, "Learning may be defined as the process by with a relatively enduring change in behaviour occurs as result of experience or practice". ((Surya, 2001). Pernyataan tersebut menegaskan bahwa indikator belajar ditujukan dengan perubahan dalam tingkah laku hasil dari pengalaman.

Komponen input diklasifikasikan menjadi tiga, yaitu (1) raw input, yaitu siswa yang meliputi intelek, fisikkesehatan, sosial-afektif dan peer group. (2) Instrumental input, meliputi kebijakan pendidikan, program pendidikan (kurikulum), personil (kepala sekolah, guru, staf TU), sarana, fasilitas, media, dan biaya, dan (3) Environmental input, meliputi lingkungan sekolah, lingkungan keluarga, masyarakat, dan lembaga sosial, unit kerja. (Sukmadinata \& Syaodih, 2006)

Konsep mutu pembelajaran mengandung lima rujukan, yaitu: “(1) kesesuaian, (2) daya tarik, (3) efektivitas, (4) efisiensi dan (5) produktivitas pembelajaran”. (Muljono, 2006)

"Pembelajaran pada hakekatnya adalah proses interaksi antara peserta didik dengan lingkungannya, sehingga terjadi perubahan perilaku ke arah yang lebih baik”. (Mulyasa, 2002)

Cronbach menyatakan, "Learning may be defined as the process by with a relatively enduring change in behaviour occurs as result of experience or practice". Pernyataan tersebut menegaskan bahwa indikator belajar ditujukan dengan perubahan dalam tingkah laku hasil dari pengalaman. (Surya, 2001)

Ada empat hal yang terkait dengan proses pembelajaran, yaitu perencanaan, pelaksanaan, penilaian dan pengawasan. (Rusman, 2012)

Pembinaan adalah "suatu kegiatan mempertahankan dan menyempurnakan 
apa yang telah ada." (Soetopo dan Soemanto, 1991)

Pembinaan adalah "suatu usaha yang dilakukan dengan sadar, berencana, teratur, dan terarah untuk meningkatkan sikap dan keterampilan seseorang dengan tindakan-tindakan, pengarahan, pembimbingan, pengembangan dan stimulasi dan pengawasan untuk mencapai suatu tujuan". (Hidayat, 2006)

Rensis Likert menyatakan bahwa 'dalam organisasi yang dipimpin oleh perilaku struktur tugas prestasi kerja baik tetapi banyak terjadi absensi dan keluhan. (Handoko, 2003)

Fungsi kepemimpinan adalah "memandu, menuntun, membimbing, membangun, memberi motivasi kerja, mengemudikan organisasi, menjalin jaringan komunikasi yang baik, memberi supervisi dan pengawasan yang efisien, dan membawa pengikutnya kepada sasaran yang ingin dituju sesuai dengan ketentuan waktu dan perencana.” (Kartono, 2001)

Kegiatan-kegiatan pokok yang harus diperhatikan dalam pembinaan kepegawaian meliputi: (1) Penentuan kebutuhan, (2) Pengadaan,

Penempatan, (4) Pengendalian,

Peningkatan moril, (6) Peningkatan mutu, dan (7) Pemeliharaan tata usaha kepegawaian (Wijaya, 1995).
Pembinaan pegawai diarahkan pada: (1). Satuan organisasi mempunyai jumlah dan mutu pegawai yang rasional, sesuai dengan jenis, sifat dan beban kerja yang dibebankan kepadanya. (2). Pembinaan seluruh pegawai terintegrasi artinya terhadap semua pegawai berlaku ketentuan yang sama. (3). Pembinaan pegawai dilaksanakan atas dasar sistem karir dan sistem prestasi. (4). Pengembangan sistem penggajian diarahkan untuk menghargai prestasi kerja dan besarnya tanggung jawab. (5). Tindakan korektif terhadap pegawai yang benar-benar melanggar ketentuan yang berlaku dilaksanakan secara tegas. (6). Penyempurnaan sistem administrasi kepegawaian dan sistem pengawasannya dapat dilaksanakan. (7). Pembinaan dan kesetiaan serta ketaatan penuh terhadap Pancasila, Undang-Undang Dasar 1945, Negara dan pemerintah tetap terjamin. (Wursanto, 1997)

Pembinaan pegawai adalah suatu upaya pengendalian dan pengawasan pegawai yang dilakukan secara berkesinambungan untuk mempertahankan kedisiplinan, tanggung jawab, kepatuhan pegawai terhadap kebijakan atau aturan yang berlaku dalam organisasi. (Miftah Thoha, 1997)

Pembinaan sebagai suatu proses pengendalian, pemeliharaan, pengawasan 
dan pengelolaan sumber daya aparatur, infrastruktur, sumberdaya finansial, waktu, metode dan sistem disiplin kerja yang didasarkan pada prinsip keteraturan untuk pencapaian prestasi kerja pegawai yang profesional, efektif dan efisien. (Mussanef,1996)

Empat faktor yang mempengaruhi kinerja, yaitu: 1) Motivasi para pekerja, 2) kemampuan dan keterampilanketerampilan, 3) kejelasan aturan dan penerimaan tugas dan 4) kesempatan untuk berkinerja. (Steers, 2005)

"Guru yang profesional adalah guru yang memiliki kompetensi: menguasai bahan yang diajarkan, (2) mengelola program pembelajaran, (3) mengelola kelas, (4) menggunakan sumber dan media, (5) menguasai landasan kependidikan, (6) mengelola interaksi pembelajaran, (7) menilai prestasi siswa.” (Rahman Abror, 1993)

\section{METODE PENELITIAN}

Penelitian ini menggunakan pendekatan kuantitatif. Sekolah yang menjadi populasi dalam penelitian ini adalah sekolah dasar negeri di Kecamatan Ciawigebang Kabupaten Kuningan. Dengan demikian populasi yang dijadikan responden dalam penelitian ini adalah semua guru dan kepala sekolah dengan asumsi bahwa kepala sekolah adalah guru yang mendapat tugas tambahan pada sekolah dasar negeri di Kecamatan Ciawigebang Kabupaten Kuningan, yang berjumlah 415 orang.

Penulis mengambil sampel dengan teknik simple random sampling atau teknik acak sederhana sebanyak $15 \%$ dari total populasi, sehingga jumlah sampel dalam penelitian ini adalah 62,25 dibulatkan menjadi 62 orang.

\section{HASIL DAN PEMBAHASAN}

Untuk mengetahui besarnya pengaruh pembinaan oleh kepala sekolah (X1) secara individual (parsial) terhadap kualitas proses pembelajaran kelas V (Y) dapat dilihat dari nilai $\mathrm{t}$ pada tabel Coeffiients dibawah ini dengan kriteria pengujian jika tingkat signifikansi lebih kecil dari 0,05, maka hipotesis diterima. Adapun hasil pengujian hipotesis tersebut adalah sebagai berikut tercantum tabel 1 : 


\section{Tabel 1}

\section{Uji Hipotesis ( $t$ ) Variabel $\mathrm{X}_{1}$ terhadap $\mathrm{Y}$}

\begin{tabular}{|c|c|c|c|c|c|c|}
\hline \multirow{2}{*}{\multicolumn{2}{|c|}{ Model }} & \multicolumn{2}{|c|}{$\begin{array}{c}\text { Unstandardized } \\
\text { Coefficients } \\
\end{array}$} & \multirow{2}{*}{$\begin{array}{c}\text { Standardized } \\
\text { Coefficients } \\
\text { Beta } \\
\end{array}$} & \multirow[b]{2}{*}{$\mathrm{T}$} & \multirow[b]{2}{*}{ Sig. } \\
\hline & & $\mathrm{B}$ & Std. Error & & & \\
\hline \multirow[t]{2}{*}{1} & (Constant) & ,793 & 8,130 & & ,098 & ,923 \\
\hline & Pembinaan_oleh_Kasek_X1 & 1,208 &, 156 & ,706 & 7,722 &, 000 \\
\hline
\end{tabular}

Berdasarkan tabel hasil uji $\mathrm{t}$ diperoleh bahwa nilai thitung variabel pembinaan oleh kepala sekolah (X1) memiliki nilai sebesar p-value $0,000<0,05$ artinya berdistribusi signifikan. Hal tersebut berarti pembinaan oleh kepala sekolah (X1) secara parsial berpengaruh terhadap kualitas proses pembelajaran kelas V (Y). Hal tersebut berarti menerima hipotesis yang menyatakan : "Terdapat pengaruh positif dan signifikan pembinaan oleh kepala sekolah terhadap kualitas proses pembelajaran kelas V Pada SD Negeri di Kecamatan Ciawigebang Kabupaten Kuningan ".

Persamaan regresi $\mathrm{y}=\mathrm{a} \mathrm{bx} 1$ dari hasil perhitungan diperoleh $\mathrm{y}=0,793+$ 1,208X1. Konstanta sebesar 0,793 menyatakan bahwa jika ada kenaikan nilai dari variabel pembinaan oleh kepala sekolah (X1), maka kualitas proses pembelajaran kelas V (Y) adalah 0,793. Koefesien regresi sebesar 1,208 menyatakan bahwa setiap perubahan satu skor atau nilai pembinaan oleh kepala sekolah akan memberikan skor 1,208.

Untuk mengetahui besaran pengaruh kinerja mengajar guru (X2) secara individual (parsial) terhadap kualitas proses pembelajaran kelas V (Y) dapat dilihat dari nilai t pada tabel Coefficients dibawah ini dengan kriteria pengujian jika tingkat signifikansi lebih kecil dari 0,05, maka hipotesis diterima. Adapun hasil pengujian hipotesis tersebut adalah sebagai berikut:

Tabel 2

\section{Uji Hipotesis ( $t$ ) Variabel $X_{2}$ terhadap $Y$}

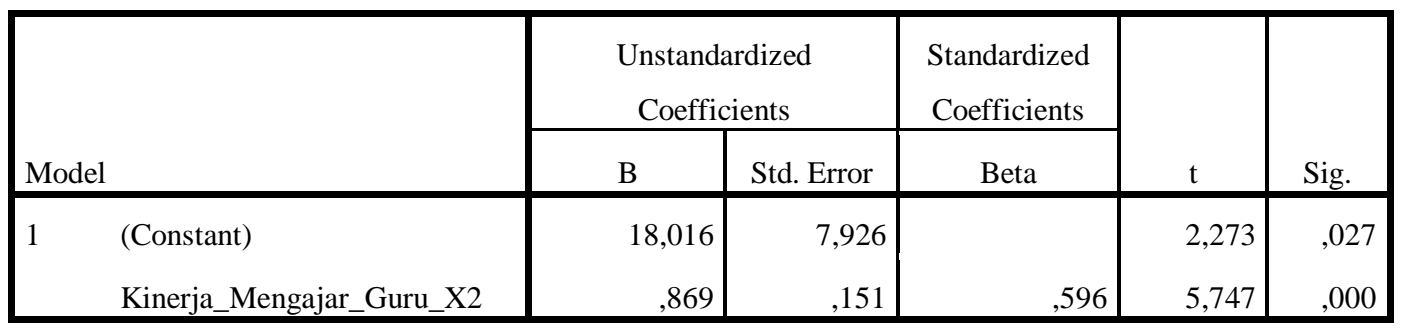


Berdasarkan tabel hasil uji t diperoleh bahwa nilai thitung variabel kinerja mengajar guru (X2) memiliki nilai sebesar p-value $0,000<0,05$ artinya signifikan. Dengan demikian kinerja mengajar guru (X2) secara parsial berpengaruh terhadap kualitas proses pembelajaran kelas V (Y). Hal tersebut mengandung makna diterimanya hipotesis yang menyatakan: "Terdapat pengaruh positif dan signifikan kinerja mengajar guru terhadap kualitas proses pembelajaran kelas V pada SD Negeri di Kecamatan Ciawigebang Kabupaten Kuningan".

Persamaan regresi $\mathrm{y}=\mathrm{a} b \mathrm{~b} 2$ dari hasil perhitungan diperoleh $\mathrm{y}=18,016+$ 0,869X2. Konstanta sebesar 18,016 menyatakan bahwa jika ada kenaikan nilai dari variabel kinerja mengajar guru (X2), maka kualitas proses pembelajaran kelas V (Y) adalah 18,016 Koefesien regresi sebesar 0,869 menyatakan bahwa setiap perubahan satu skor atau kinerja mengajar guru akan memberikan skor 0,869 .

Untuk mengetahui besarnya pengaruh pembinaan oleh kepala sekolah (X1) dan kinerja mengajar guru secara bersamasama (ganda) terhadap kualitas proses pembelajaran kelas $\mathrm{V}(\mathrm{Y})$ dapat dilihat dari nilai $\mathrm{t}$ pada tabel Coefficients dibawah ini dengan kriteria pengujian jika tingkat signifikansi lebih kecil dari 0,05, maka hipotesis diterima. Adapun hasil pengujian hipotesis tersebut adalah sebagai berikut:

Tabel 3

\section{Uji Hipotesis (t) Variabel $X_{1}$ dan $X_{2}$ terhadap Y}

\begin{tabular}{|c|c|c|c|c|c|c|}
\hline \multirow{2}{*}{\multicolumn{2}{|c|}{ Model }} & \multicolumn{2}{|c|}{$\begin{array}{c}\text { Unstandardized } \\
\text { Coefficients }\end{array}$} & \multirow{2}{*}{$\begin{array}{c}\text { Standardized } \\
\text { Coefficients } \\
\text { Beta } \\
\end{array}$} & \multirow[b]{2}{*}{$\mathrm{t}$} & \multirow[b]{2}{*}{ Sig. } \\
\hline & & $\mathrm{B}$ & Std. Error & & & \\
\hline \multirow[t]{3}{*}{1} & (Constant) & 5,073 & 8,201 & &,- 619 &, 539 \\
\hline & Pembinaan_oleh_Kasek_X1 &, 933 &, 189 &, 545 & 4,925 &, 000 \\
\hline & Kinerja_Mengajar_Guru_X2 & ,387 & 161 & ,265 & 2,396 & 020 \\
\hline
\end{tabular}

Berdasarkan tabel hasil uji $\mathrm{t}$ diperoleh bahwa nilai thitung variabel pembinaan oleh kepala sekolah (X1) dan kinerja mengajar guru (X2) secara bersama-sama (simultan) memiliki nilai sebesar $\mathrm{p}$-value $0,000<0,05$ artinya signifikan. Dengan demikian pembinaan oleh kepala sekolah (X1) dan kinerja mengajar guru (X2) secara bersama-sama (simultan) berpengaruh terhadap kualitas proses pembelajaran kelas V (Y). Hal tersebut membuktikan diterimanya hipotesis yang 
menyatakan: "Terdapat pengaruh positif dan signifikan pembinaan oleh kepala sekolah dan kinerja mengajar guru secara simultan terhadap kualitas proses pembelajaran kelas V pada SD Negeri di Kecamatan Ciawigebang Kabupaten Kuningan ".

Pembahasan penelitian ini pertama, permasalahan yang ingin dijawab dalam penelitian ini adalah adakah pengaruh pembinaan oleh kepala sekolah terhadap kualitas proses pembelajaran kelas $\mathrm{V}$ pada SD Negeri di Kecamatan Ciawigebang Kabupaten Kuningan. Secara empirik, hasil penelitian ini menginformasikan: (1) terdapat pengaruh positif dan signifikan antara pembinaan oleh kepala sekolah terhadap kualitas proses pembelajaran kelas $\mathrm{V}$ pada SD Negeri di Kecamatan Ciawigebang Kabupaten Kuningan, serta (2) besarnya pengaruh pembinaan oleh kepala sekolah terhadap kualitas proses pembelajaran kelas V pada SD Negeri di Kecamatan Ciawigebang Kabupaten Kuningan ditunjukkan oleh hasil penelitian bahwa pembinaan oleh kepala sekolah yang terdiri dari dimensi: (1) Tindakan perbaikan; (2) Strategi perubahan; (3) Perencanaan perubahan; (3) Efektivitas perubahan (Thoha, 1997), membawa implikasi yang signifikan terhadap kualitas proses pembelajaran kelas $\mathrm{V}$ yang meliputi dimensi: (1) Kesesuaian, (2) Daya tarik, (3) Efektivitas, (4) Efisiensi; (5) Produktivitas (Muljono, 2006).

Namun demikian kualitas proses pembelajaran kelas V pada SD Negeri di Kecamatan Ciawigebang Kabupaten Kuningan ini tidak hanya dipengaruhi oleh pembinaan oleh kepala sekolah saja, ada faktor lain (epsilon), selain dari kinerja mengajar guru, yang juga berpengaruh, yang tidak dikaji dalam penelitian ini. Dengan demikian, hasil penelitian ini mengindikasikan bahwa semakin baik pembinaan oleh kepala sekolah pada SD Negeri di Kecamatan Ciawigebang Kabupaten Kuningan, maka akan diikuti oleh semakin tingginya kualitas proses pembelajaran kelas V.

Kedua, Permasalahan yang ingin dijawab dalam penelitian ini adalah adakah pengaruh kinerja mengajar guru terhadap kualitas proses pembelajaran kelas V pada SD Negeri di Kecamatan Ciawigebang Kabupaten Kuningan. Secara empirik, hasil penelitian ini menginformasikan: (1) terdapat pengaruh positif dan signifikan antara kinerja mengajar guru terhadap kualitas proses pembelajaran kelas V pada SD Negeri di Kecamatan Ciawigebang Kabupaten Kuningan, serta (2) besarnya pengaruh kinerja mengajar guru terhadap kualitas 
proses pembelajaran kelas $\mathrm{V}$ pada $\mathrm{SD}$ Negeri di Kecamatan Ciawigebang Kabupaten Kuningan ditunjukkan oleh hasil penelitian bahwa kinerja mengajar guru yang terdiri dari dimensi: (1) Perencanaan pembelajaran;

Pelaksanaan pembelajaran; (3) Evaluasi pembelajaran; (4) Refleksi/tindak lanjut;

(5) Kompetensi profesional (Abror, 1993), membawa implikasi yang signifikan terhadap kualitas proses pembelajaran kelas $\mathrm{V}$ yang meliputi dimensi: : (1) Kesesuaian, (2) Daya tarik, (3) Efektivitas, (4) Efisiensi;

Produktivitas (Muljono, 2006). Namun demikian kualitas proses pembelajaran kelas V Pada SD Negeri di Kecamatan Ciawigebang Kabupaten Kuningan ini tidak hanya dipengaruhi oleh kinerja mengajar guru saja, ada faktor lain (epsilon), selain dari pembinaan oleh kepala sekolah, yang juga berpengaruh, yang tidak dikaji dalam penelitian ini.

Dengan demikian, hasil penelitian ini mengindikasikan bahwa semakin baik kinerja mengajar guru pada SD Negeri di Kecamatan Ciawigebang Kabupaten Kuningan, maka akan diikuti oleh semakin tingginya kualitas proses pembelajaran kelas V. Hal ini dapat diterangkan oleh persamaan regresi $\mathrm{y}=$ $18,016+0,869 X 2$. Dengan persamaan regresi tersebut dapat diinterpretasikan bahwa jika kinerja mengajar guru (X2) dengan kualitas proses pembelajaran kelas V (Y) diukur dengan instrumen yang dikembangkan dalam penelitian ini, maka setiap perubahan skor kualitas proses pembelajaran kelas $\mathrm{V}$ sebesar satu satuan dapat diestimasikan skor kualitas proses pembelajaran kelas $\mathrm{V}$ akan berubah 0,869 satuan pada arah yang sama.

Ketiga, Permasalahan yang ingin dijawab dalam penelitian ini adalah adakah pengaruh pembinaan oleh kepala sekolah, dan kinerja mengajar guru terhadap kualitas proses pembelajaran kelas V pada SD Negeri di Kecamatan Ciawigebang Kabupaten Kuningan. Secara empirik, hasil penelitian ini menginformasikan: (1) terdapat pengaruh positif dan signifikan antara pembinaan oleh kepala sekolah dan kinerja mengajar guru secara simultan terhadap kualitas proses pembelajaran kelas $\mathrm{V}$ pada SD Negeri di Kecamatan Ciawigebang Kabupaten Kuningan, serta (2) besarnya pengaruh pembinaan oleh kepala sekolah dan kinerja mengajar guru terhadap kualitas proses pembelajaran kelas $\mathrm{V}$ pada SD Negeri di Kecamatan Ciawigebang Kabupaten Kuningan ditunjukkan oleh hasil penelitian bahwa pembinaan oleh kepala sekolah yang terdiri dari dimensi: (1) Tindakan 
perbaikan; (2) Strategi perubahan; (3) Perencanaan perubahan; (3) Efektivitas perubahan (Thoha, 1997), serta kinerja mengajar guru yang terdiri atas dimensi:

(1) Perencanaan pembelajaran;

Pelaksanaan pembelajaran; (3) Evaluasi pembelajaran; (4) Refleksi/tindak lanjut;

(5) Kompetensi profesional (Abror, 1993), membawa implikasi yang signifikan terhadap kualitas proses pembelajaran kelas $\mathrm{V}$ yang meliputi dimensi: (1) Kesesuaian, (2) Daya tarik, (3) Efektivitas, (4) Efisiensi;

Produktivitas (Muljono, 2006).

Namun demikian kualitas proses pembelajaran kelas V pada SD Negeri di Kecamatan Ciawigebang Kabupaten Kuningan ini tidak hanya dipengaruhi oleh pembinaan oleh kepala sekolah, dan kinerja mengajar guru saja, ada faktor lain (epsilon), yang juga berpengaruh, yang tidak dikaji dalam penelitian ini. Dengan demikian, hasil penelitian ini mengindikasikan bahwa semakin baik pembinaan oleh kepala sekolah, dan semakin bagus kinerja mengajar guru pada SD Negeri di Kecamatan Ciawigebang Kabupaten Kuningan, maka akan diikuti oleh semakin tingginya kualitas proses pembelajaran kelas V. Hal ini dapat diterangkan oleh persamaan regresi: $\quad \mathrm{Y}^{\wedge}=5,073+0,933 \mathrm{X} 1+0,387 \mathrm{X} 2$
Dengan persamaan regresi tersebut dapat diinterpretasikan bahwa jika pembinaan oleh kepala sekolah (X1), dan kinerja mengajar guru (X2) dengan kualitas proses pembelajaran kelas V (Y) diukur dengan instrumen yang dikembangkan dalam penelitian ini, maka setiap perubahan skor pembinaan oleh kepala sekolah dan kinerja mengajar guru sebesar satu satuan dapat diestimasikan skor kualitas proses pembelajaran kelas $\mathrm{V}$ akan berubah 0,933 dan 0,387 satuan pada arah yang sama.

Berdasarkan temuan empirik yang menunjukkan adanya pengaruh yang signifikan pembinaan oleh kepala sekolah, dan kinerja mengajar guru terhadap kualitas proses pembelajaran kelas V, maka hasil penelitian ini memberikan beberapa informasi, di antaranya: (1) pembinaan oleh kepala sekolah, dan kinerja mengajar guru pada SD Negeri di Kecamatan Ciawigebang Kabupaten Kuningan memberikan kontribusi yang berarti terhadap kualitas proses pembelajaran kelas V, (2) salah satu cara untuk meningkatkan kualitas proses pembelajaran kelas $\mathrm{V}$ pada $\mathrm{SD}$ Negeri di Kecamatan Ciawigebang Kabupaten Kuningan adalah dengan meningkatkan pembinaan oleh kepala sekolah dan kinerja mengajar guru. (3) persentase kontribusi atau pengaruh yang 
diberikan oleh pembinaan oleh kepala sekolah dan kinerja mengajar guru secara simultan terhadap kualitas proses pembelajaran kelas $\mathrm{V}$ adalah sebesar $54,3 \%$, sementara sisanya dipengaruhi oleh variabel lain, yang tidak dikaji dalam penelitian ini (epsilon).

\section{PENUTUP}

Setelah penjabaran hasil penelitian dan pembahasan pada Bab IV, pada bab ini penulis dapat menampilkan kesimpulan, bahwa:

1) Terdapat pengaruh yang positif dan signifikan pembinaan oleh kepala sekolah terhadap kualitas proses pembelajaran kelas V pada SD Negeri di Kecamatan Ciawigebang Kabupaten Kuningan. Besaran pengaruh pembinaan oleh kepala sekolah terhadap kualitas proses pembelajaran kelas $\mathrm{V}$ pada $\mathrm{SD}$ Negeri di Kecamatan Ciawigebang Kabupaten Kuningan adalah 49,8\%.

2) Terdapat pengaruh yang positif dan signifikan kinerja mengajar guru terhadap kualitas proses pembelajaran kelas V pada SD Negeri di Kecamatan Ciawigebang Kabupaten Kuningan. Besaran pengaruh kinerja mengajar guru terhadap kualitas proses pembelajaran kelas V pada SD Negeri di Kecamatan Ciawigebang Kabupaten Kuningan adalah $35,5 \%$.
3) Terdapat pengaruh yang positif dan signifikan pembinaan oleh kepala sekolah dan kinerja mengajar guru secara simultan terhadap kualitas proses pembelajaran kelas V pada SD Negeri di Kecamatan Ciawigebang Kabupaten Kuningan. Besaran pengaruh pembinaan oleh kepala sekolah dan kinerja mengajar guru secara simultan terhadap kualitas proses pembelajaran kelas $\mathrm{V}$ pada SD Negeri di Kecamatan Ciawigebang Kabupaten Kuningan adalah 54,3\%.

\section{UCAPAN TERIMAKASIH}

Terimkasih kepada semua pihak yang telah membantu penulisan karya ilmiah ini.

\section{DAFTAR PUSTAKA}

Crosby, Philip B., (2001). Quality Without Tears: The Art of HassleFree Management, New York: Mc. Graw Hill Book Company.

Handoko, T. Hani. (2003). Manajemen Personalia. Yogyakarta : BPFE.

Hidayat, (2006), Konsep Dasar dan Pengertian Produktivitas Serta Interpretasi Hasil Pengukurannya. Bandung: Prisma.

Juran, J.M, (2000), Merancang Mutu, Terjemahan Bambang Hartono dari Juran On Quality By Design, Jakarta: PT. Pustaka Binawan Pressindo. 
Mulyasa, E. (2002). Manajemen Berbasis Sekolah Konsep, Strategi dan Implementasi. Bandung: Remaja Rosdakarya.

Muljono, P. (2006). Standar Proses Pembelajaran. Jakarta: Buletin BSNP. Vol. I/No. 2/Mei 2006

Rohiat. (2010). Manajemen Sekolah, Teori Dasar dan Praktik. Bandung: PT Refika Aditama

Rusman, (2012). Model-model Pembelajaran: mengembangkan Profesionalisme Guu, Jakarta: PT. Raja Grafindo Persada.

Surya, Mohammad (2001), Psikologi Pembelajaran dan Pengajaran, Bandung: Pustaka Bani Quraisy

Soetopo dan Sumanto. (1991). Keguruan: Jakarta: Bina Aksara.

Tampubolon, Daulat P., (2002). Perguruan Tinggi Bermutu: Paradigma Baru Manajemen Pendidikan Tinggi Menghadapi Tantangan Abad Ke-21. Jakarta: Gramedia Pustaka Utama. h. 108

Tenner, A.R, dan De Toro, I.J (2002), Total Quality Management: Three Steps To Continuous Improvement, Reading, MA: Addison-Wesley Publishing Company. 